\title{
A new species of Atypus Latreille, 1804 (Araneae: Atypidae) from Northern India
}

\author{
Новый вид рода Atypus Latreille, 1804 (Araneae: Atypidae) \\ из северной Инаии
}

\author{
Manju Siliwal ${ }^{1}$, R. Suresh Kumar ${ }^{2}$ and Robert Raven ${ }^{3}$ \\ М. Симиван ${ }^{1}$, Р.С. Кумар², Р. Равен ${ }^{3}$
}

\author{
${ }^{1}$ Wildlife Information Liaison Development Society, 96 Kumudham Nagar, Villankurichi Road, Coimbatore 641035, Tamil Nadu, India. \\ E-mail: manjusiliwal@gmail.com \\ ${ }^{2}$ Wildlife Institute of India, Post Box. 18, Chandrabani, Dehradun, Uttarakhand, India. E-mail: suresh@wii.gov.in \\ ${ }^{3}$ Queensland Museum, Grey Street, PO Box 3300, South Brisbane, 4101, Queensland, Australia. E-mail: robertjraven@gmail.com
}

\author{
KEY WORDS: Mygalomorphae, new species, taxonomy, Dehradun. \\ КЛЮЧЕВЫЕ СЛОВА: Mygalomorphae, новый вид, таксономия, Дерадун.
}

\begin{abstract}
Atypus wii sp.n. $\left(O^{7}\right)$, the second Indian representative of the genus, is described from Uttarakhand. The new species differs from $A$. sutherlandi Chennappaiya, 1935, the only Indian congener known hitherto, by carapace, chelicerae and legs being brown and darker in colour; longer scutum; embolus as long as the conductor and not exceeding beyond conductor length and spines present on all metatarsi and tarsi II-IV.
\end{abstract}

РЕЗЮМЕ. Описан Atypus wii sp.n. $\left(\sigma^{7}\right)$, второй представитель рода в Индии (штат Уттаракханд). Новый вид отличается от другого индийского вида A. sutherlandi Chennappaiya, 1935, формой карапакca, хелицер и более тёмными ногами. Кроме того новый вид имеет более длинный скутум, эмболюс равный по длине кондуктору и наличием шипов на всех предлапках и лапках II-IV.

\section{Introduction}

The family Atypidae is represented by three genera and 49 species in the world, of which, only single species Atypus sutherlandi Chennappaiya, 1935 is reported from India [cf. Platnick, 2014] and is known only from the type locality, Kalimpong, Darjeeling District, West Bengal [Gravely, 1935]. Apart from that record, there have been no reports of Atypus from India at all, though Gravely [1935] and Schwendinger [1990] mentioned that in the collection of the Indian Museum, there were some unidentified, dried and damaged specimens from tea estate in Kilkundha, Tamil Nadu in Nilgiri Hills but they remained undescribed. Moreover, no fresh specimens were recorded or collected from these areas. The present study is based on the occurrence of the second Indian congener after about 80 years from the first species description; this species was revealed to be a undescribed member of the genus; the diagnosis and the illustrative description of the new taxon are provided below. Comparison of the new species with other reported species is based information available in two major revisions for this genus by Schwendinger [1990] and Zhu et al. [2006] and other published literature [Hu, 1994; Oliger, 1999; Kim et al., 2006; Tanikawa, 2006].

\section{Material and Methods}

The holotype is deposited at Wildlife Information Liaison Development Society, Coimbatore, Tamil Nadu, India. Measurements of body parts, except for the eyes, were taken with a Mitutoyo ${ }^{\mathrm{TM}}$ Vernier Caliper. Eye measurements were done with calibrated ocular micrometer. Legs and pedipalp measurements were taken on the left side and all measurements were taken dorsally. All measurements are in millimeters. Total length excludes chelicerae and spinnerets. All illustrations were prepared with the help of a camera lucida attached to a MOTIC ${ }^{\mathrm{TM}}$ stereomicroscope by MS. Abbreviations: ALE - anterior lateral eye, ALS - anterior laterial spinnerets, AME - anterior median eye, MOQ - median ocular quadrate, PLE — posterior lateral eye, PME — posterior median eye, PLS - posterior lateral spinnerets, PMS - posterior median spinnerets, WILD - Wildlife Information Liaison Development Society. Abbreviations used for hair and spines count are $\mathrm{d}$ - dorsal, fe femur, $\mathrm{mt}$ - metatarsus, $\mathrm{p}$ - prolateral, pa - patella, $\mathrm{r}$ - retrolateral, ta - tarsus, ti - tibia, $\mathrm{v}$ - ventral.

\section{Taxonomy}

Atypus wii sp.n.

Figs 1A-I, Table 1

TYPES. Holotype $0^{\top}$, INDIA: Uttarakhand, Dehradun, Wildlife Institute of India campus $\left(30.17118^{\circ} \mathrm{N} 77.58370^{\circ} \mathrm{E}\right)$, 


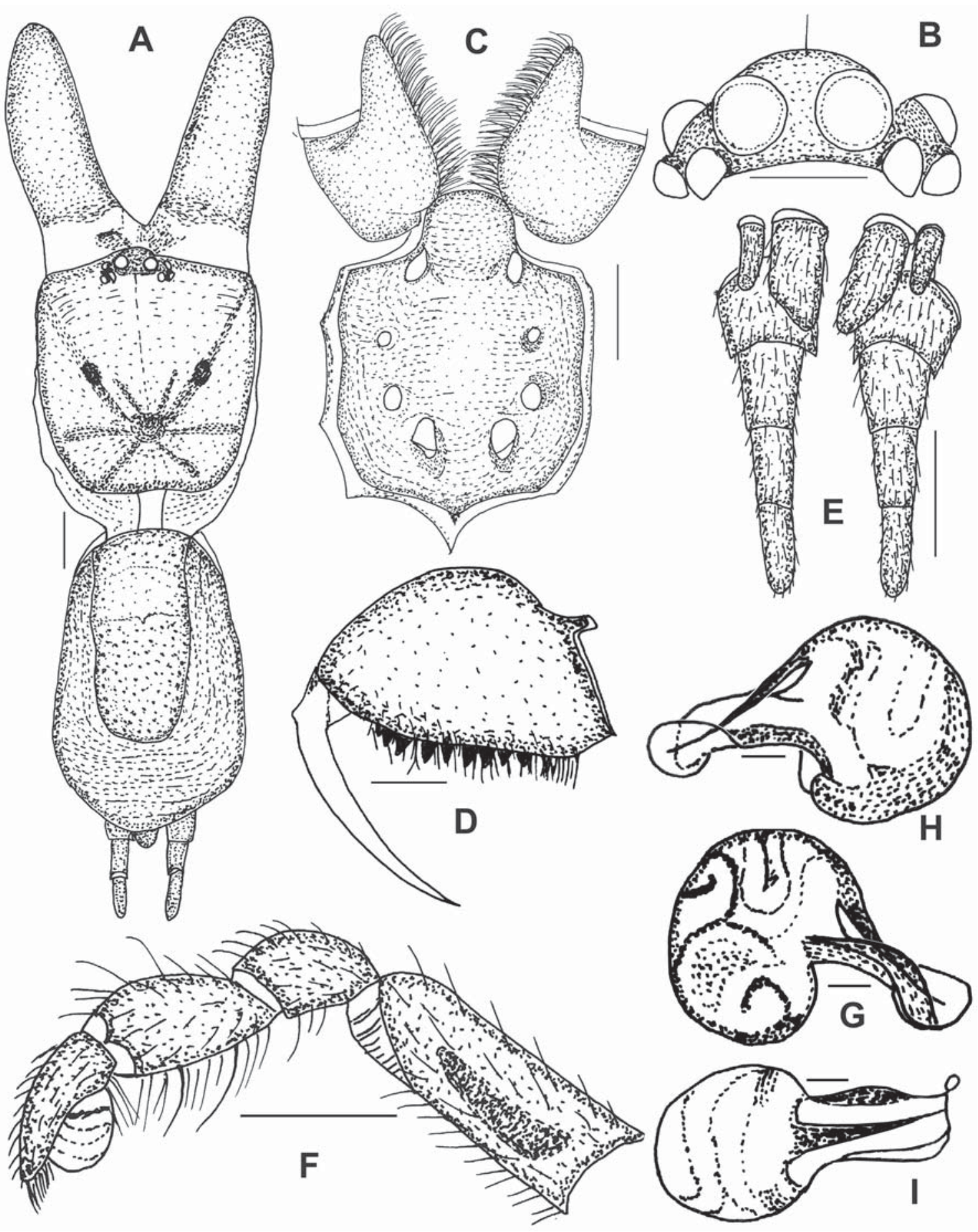

Fig. 1. Atypus wii sp.n.: A - habitus, dorsal; B - eyes; C - sternum, maxillae and labium; D - chelicerae, prolateral; $\mathrm{E}-$ spinnerets; F - palp, prolateral; G-I - bulb, prolateral, retrolateral and from above, respectively. Scale: A, C-F - $1.0 \mathrm{~mm}$; B - $0.5 \mathrm{~mm}$; $\mathrm{G}-\mathrm{I}-0.1 \mathrm{~mm}$.

Рис. 1. Atypus wii sp.n.: А — габитус, сверху; В — глаза; С - стернум, максиллы и лабиум; D - хелицера, пролатерально; Е - бородавки; F - пальпа, пролатерально; G-I - бульбус, пролатерально, ретролатерально и сверху, соответственно. Масштаб: A, C-F - 1,0 мм; B-0,5 мм; G-I - 0,1 мм. 
7.08.2012, coll. Manju Siliwal and Suresh Kumar (WILD-12-ARA1129).

ETYMOLOGY. The species epithet is an acronym for Wildlife Institute of India, where the spider was collected.

DIAGNOSIS. The new species differs from $A$. sutherlandi by the carapace and chelicerae being reddishbrown and the legs and palp being greenish-brown except for the distal part of the metatarsi and complete tarsi of all legs and palp yellowish (in A. sutherlandi, the carapace, chelicerae and legs are yellowish); abdominal scutum for about $2 / 3^{\text {rd }}$ length of abdomen (in A. sutherlandi only for about $1 / 2$ length of the abdomen); embolus is as long as the conductor (in $A$. sutherlandi, embolus extends beyond the conductor length); spines are present on all metatarsi and tarsi II-IV (in $A$. sutherlandi, spines practically absent on metatarsi IV and all tarsi). The new species closely resembles other Asian species, A. sternosulcus Kim et al., 2006, A. quelpartensis Namkung, 2002 and A. suwonensis Kim et al., 2006 in having four segmented PLS, nonpigmented area on connective tissue of retrolateral patellae, conductor strongly bent, spines on metatarsi IV, but differs by having oval sigilla IV (A. sternosulcus with triangular sigilla); granules on femora I (in $A$. quelpartensis and $A$. suwonensis granules absent on femora I-II); differs from rest of the species by the upper corner of the conductor bent either less distinct ( $A$. affinis Eichwald, 1830, A. wataribabaorum Tanikawa, 2006, A. formosensis Kayashima, 1943, A. heterothecus Zhang, 1985, A. javanus Thorell, 1890) or absent (A. dorsualis Thorell, 1897, A. suthepicus Schwendinger, 1989); differs from A. lannaianus Schwendinger, 1989 by sigilla IV not triangular; differs from $A$. baotianmanensis $\mathrm{Hu}$, 1994, A. flexus Zhu et al., 2006, A. tibetensis Zhu et al., 2006, A. yajuni Zhu et al., 2006, A. medius Oliger, 1999, A. largosaccatus Zhu et al., 2006 and $A$. sinensis Schenkel, 1953 by dorsal spines present on mt IV and granules present only on fe I; differs from A. pedicellatus Zhu et al., 2006 by conductor bend distinct and differs from A. sacculatus Zhu et al., 2006 by sigilla I marginal.

DESCRIPTION. Male. Total length 8.68. Carapace 3.98 long, 3.68 wide; chelicerae 3.41 long; abdomen 4.70 long, 3.33 wide. Spinnerets: ALS, 0.43 long, 0.12 wide; PMS, 0.75 long, 0.44 wide, 0.26 apart; PLS, 0.52 basal, 0.61 middle, 0.55 subapical, 0.66 apical; midwidths $0.59,0.46,0.33,0.17$ respectively; 2.34 total length.

Colour in life: Carapace, chelicerae, sternum, maxillae black. Legs and palp black except for tarsi of all legs and palp orangish, distal $1 / 4^{\text {th }}$ ti and distal $3 / 4^{\text {th }} \mathrm{mt}$ on all legs paler. Abdomen dorsally uniformly grayish-black, scutum, black; ventrally and ventro-laterally uneven shades of grayish-brown except for book-lung and epigastric area, yellowish. Spinnerets greenish-brown.

Colour in alcohol: carapace, chelicerae reddishbrown; caput and margins darker; eye tubercle black. Sternum, labium and maxillae reddish-brown, paler longitudinal band running for length on proventral max-
Table 1. Morphometry of legs and palp of Atypus wii sp.n. Таблица 1. Морфометрия ног и пальпы Atypus wii sp.n.

\begin{tabular}{|l|c|c|c|c|c|}
\hline & LEG I & $\begin{array}{c}\text { LEG } \\
\text { II }\end{array}$ & $\begin{array}{c}\text { LEG } \\
\text { III }\end{array}$ & $\begin{array}{c}\text { LEG } \\
\text { IV }\end{array}$ & PALP \\
\hline Femur & 3.84 & 3.38 & 2.58 & 3.85 & 1.75 \\
\hline Patella & 1.74 & 1.60 & 1.24 & 1.50 & 0.75 \\
\hline Tibia & 2.19 & 1.80 & 1.42 & 2.20 & 0.94 \\
\hline Metatarsus & 3.01 & 2.68 & 2.65 & 3.56 & - \\
\hline Tarsus & 2.24 & 2.18 & 2.20 & 2.76 & 0.87 \\
\hline Total & 13.02 & 11.64 & 10.09 & 13.87 & 4.31 \\
\hline \multicolumn{7}{|c|}{ Midwidth } \\
\hline Femur & 0.66 & 0.72 & 0.82 & 0.65 & 0.39 \\
\hline Tibia & 0.61 & 0.62 & 0.62 & 0.54 & 0.52 \\
\hline
\end{tabular}

illae. Leg coxae greenish-brown, covered with short and long black bristles. Legs and palp greenish-brown except for tarsi of all legs and palp yellowish, distal 1/ $4^{\text {th }}$ ti and distal $3 / 4^{\text {th }} \mathrm{mt}$ on all legs slightly paler. Legs and palps (including coxae and maxillae) appear pigmented as area surrounding hair root yellowish. Abdomen dorsally, laterally and ventrally uniformly grayish-black with irregular yellowish lines appearing like cracks, scutum, brownish with yellowish longitudinal band mid dorsally, covered with fine short hairs, area surrounding hair yellowish due to which scutum pigmented; book lung and epigastric area, yellowish. Spinnerets greenish-brown except for ventral $1 / 4^{\text {th }}$ distal PMS and distal three segments of PLS creamish.

Carapace (Fig. 1A): rectangular, glabrous. Caput high, covers $2 / 3^{\text {rd }}$ area of carapace. Two distinct cephalic sigilla on either side of caput posteriorly. Fovea pitlike, squarish, deep. Bristles absent.

Eyes (Figs 1A-B): ocular group 0.39 long, 1.13 wide; MOA not square, 0.62 anterior width and 0.94 posterior width, 0.39 long; anterior eye row clearly recurved, posterior slightly recurved; posterior row wider than anterior row. Diameter AME 0.18, PME 0.11, ALE 0.14, PLE 0.09; distance between ALE-AME 0.02, AME-AME 0.09, PME-PME 0.63, ALE-PLEPME adjacent. Maxillae (Fig. 1C): 1.81 long anteriorly, 1.13 long posteriorly, 1.27 wide; no cuspules; anterior lobe distinct and long, no cuspules or spines; posterior edge obscured, anterior edge straight.

Labium (Fig. 1C): 0.59 long, 0.84 wide; merged or contiguous with sternum, no cuspules.

Chelicerae (Figs 1D): geniculate, rough or granulate; 8 teeth and one denticle on promargin; rastellum absent.

Sternum (Fig. 1C): 2.58 long, 2.35 wide, squarish; elevated in centre, sloping laterally, contiguous with labium, fine small ridges all over sternum and labium; long and deep ridges between sigilla and margins; uniformly covered with short black hair; row of hair on margins, posterior angle acute.

Sigilla (Fig. 1C): four pairs; first pair — anterior, marginal, oval; II-III pairs - round, remote from margin; IV pair — roughly oval, remote from margin.

Legs: All legs cylindrical, subequal in size; metatarsi of all legs longer than tarsi. All tarsi slightly bent or curved. Legs covered with fine small brown or pal- 
lid hairs and small black spines. Two conspicuous glabrous bands of variable length on dorsal of femora, patellae and tibiae. Fe I granulate. Retrolateral pa I white. Mt IV with dorsal spines. Leg formula 4123. One or two hairless bands or patches on lower basal half on ventral side of all coxae. Tarsal weakness evident on tarsi of all legs as discolored annulations.

Scopulae: all tarsi possess sparse or rudimentary scopulae, complete; absent elsewhere.

Leg spination: I: ti, $5 \mathrm{v}$; mt, 1p, 2d, 6r, 8v. II: ti, 1d, 7v; mt, 1p, 14d, 1r, 12v; ta, 2p, 2d, 1r. III: pa, 2d; ti, 2d, $9 \mathrm{v} ; \mathrm{mt}, 1 \mathrm{p}, 17 \mathrm{~d}, 1 \mathrm{r}, 15 \mathrm{v}$; ta, 7p, 5r. IV: ti, 11v; mt, 6p, 4d, 6r, 12v; ta, 7p, 8r. Palp: ti, 2v long bristle-like.

Trichobothria: 12 filiform in two rows in basal $3 / 4^{\text {th }}$ tibiae. Not evident on $\mathrm{mt}$ and ta.

Claws: all legs with three claws. Paired claws on legs I-II with one large and two small teeth, those claws on legs III-IV with three large unequal size and one small teeth. Unpaired tarsal claw bare, small and sharply curved.

Abdomen (Fig. 1A): uniformly covered with short brown hair, cuticle appears leathery and rough on both sides; dorsally, an oval scutum covering anterior $2 / 3^{\text {rd }}$ length of abdomen.

Spinnerets (Fig. 1E): covered with brown hairs; PLS with four segments; PMS distally truncated. Spigots prominently on distal end of ALS (single), distal 1/ $3^{\text {rd }}$ PMS, distal three segments of PLS; spinnerets appears pigmented due to spigot tips brown and area surrounding hair base discolored or paler. ALS and apical segment of PLS digitiform.

Palp (Figs 1F-I): femur with distinct shallow furrow on prolateral side; tibia and patella inflated. Cymbium normal, covering bulb; conductor wider at base and distally upper corners distinctly bent and strongly folded downward; median haematodocha fused lower portion of bulb, terminal haematodocha distinct at base of conductor; embolus gradually tapering distally and not going beyond conductor fold.

Female. Unknown.
NATURAL HISTORY. The only known specimen (holotype) was found wandering on the nature trail of the Wildlife Institute of India campus. The nature trail cut across a Sal (Shorea robusta) dominant patch with an man-made lake on one side. Intensive search was done in the area where this spider was found. Pit-fall traps were kept open for 25 nights in the area but this species was not collected. We were unable to locate more individuals in the same area, probably their numbers are naturally low inside the campus and they might be burrowing in decaying leaf litter, which makes them difficult to locate. Search efforts are still ongoing and when more individuals are discovered, systematic ecological information will be recorded.

ACKNOWLEDGEMENTS. Thanks to reviewers S.L. Zonstein, Tel-Aviv University, Israel and A. Tanikawa, Japan for reviewing and shaping this manuscript.

\section{References}

Gravely F.H. 1935. Notes on Indian mygalomorph spiders II // Records of the Indian Museum, Calcutta. Vol.37. P.69-84.

Hu J.L. 1994. A new species of spider of the genus Atypus from natural conservation of Baotianman in Henan Province, China (Araneae: Atypidae) // Acta arachnologica sinica. Vol.3. No.2. P. 127-130

Kim S.T., Kim H.S., Jung M.P., Lee J.H. 2006. Two new purseweb spiders of the genus Atypus (Araneae, Atypidae) from Korea // Journal of Arachnology. Vol.34. P.170-175.

Oliger T.I. 1999. A new Atypus from the Russian Far East (Aranei: Atypidae) // Arthropoda Selecta. Vol.7. No.3. P.201-204.

Platnick N.I. 2014. The world spider catalog, version 14.5. American Museum of Natural History, online at http://research. amnh.org/entomology/spiders/catalog/index.html DOI: 10.5531/ db.iz.0001.

Schwendinger P.J. 1990. A synopsis of the genus Atypus (Araneae, Atypidae) // Zoologica scripta. Vol.19. No.3. P.353-366.

Tanikawa A. 2006. A new species of the spider genus Atypus (Araneae: Atypidae) from Amami-ôshima, Japan // Acta arachnologica. Tokyo. Vol.55. No.1. P.25-27.

Zhu M.S., Zhang F., Song D.X., Qu P. 2006. A revision of the genus Atypus in China (Araneae: Atypidae) // Zootaxa. No.1118. P. $1-42$.

Responsible editor Yuri M. Marusik 